Mesa redonda Lima 7 de octubre del 2019

\title{
Revisitando a Ricardo Palma en el centésimo aniversario de su muerte
}

\author{
Roland Forgues \\ Investigador Independiente \\ forgues.roland@orange.fr \\ Bourg de Bigorre-Francia
}

\section{Resumen}

En este artículo se revisa el concepto de disidencia en la obra de Ricardo Palma. Utilizamos el término «disidencia» en el sentido que desarrollara Mario Vargas Llosa (1971). Revelamos aquí, brevemente, cómo la disidencia en Palma se enmascara de un aparente conformismo social y cultural destinado a cuestionar soterradamente las estructuras del poder colonial y patriarcal y su supervivencia en el Perú republicano.

Palabras: Tradiciones peruanas, disidencia, Mario Vargas Llosa, discurso subyacente, transgresión, formación de país.

\section{Abstract}

This article reviews the concept of dissent in Ricardo Palma's work. We use the term "dissent" in the sense that Mario Vargas Llosa (1971) developed. Briefly, we reveal here how the dissent in Palma is masked by an apparent social and cultural conformism destined to subtly question the structures of colonial and patriarchal power and its survival in the Peruvian republic.

Keywords: Peruvian traditions, dissent, Mario Vargas Llosa, underlying discourse, transgression, country formation. 
Roland Forgues (Francia). Escritor. Americanista y peruanista. Es autor de más de treinta libros de ensayos y entrevistas sobre el Perú y América Latina. Es Doctor Honoris Causa de Universidad Ricardo Palma. Profesor honorario de las Universidades Nacionales Mayor de San Marcos y Pedro Ruiz Gallo (Lambayeque). Es Miembro Correspondiente y Honorario de varias instituciones e institutos de investigaciones peruanas y extranjeras: Instituto Raúl Porras Barrenechea, Instituto Ricardo Palma, Escuela Superior de Folclore José María Arguedas, Instituto Literario y Cultural Hispánico de Westminster (USA), Society of Lebanon Valley College (USA). Entre otros reconocimientos, ha recibido el título de Miembro Adoptivo de la Tierra de Vallejo (Santiago de Chuco) y el Premio de Investigaciones del Instituto Literario y Cultural de Westminster (USA). 
En esta mesa redonda quisiera destacar simplemente algunas de las pistas analíticas e interpretativas que he venido desarrollando en estos últimos años en mis trabajos de lectura e interpretación de la obra de Ricardo Palma.

Si en estos momentos en que se está conmemorando el Centenario de la muerte del Patriarca de las letras peruanas se me pidiera definir su obra literaria en pocas palabras, lo haría con una sola: disidencia.

Disidencia, en el sentido que le dará más tarde Mario Vargas Llosa (1971) en la continuidad de las reflexiones del crítico y ensayista francés Maurice Blanchot (1955) en sus reflexiones sobre el "espacio literario" y la creación, sobre esa misteriosa y mágica relación que se establece en una obra literaria entre la realidad y la ficción.

Empezando por las reflexiones que el futuro premio Nobel de literatura consigna en su estudio sobre la obra de García Márquez, Historia de un deicidio, donde afirmaba entre otras cosas que "Escribir novelas es un acto de rebelión contra la realidad, contra Dios, contra la creación de Dios que es la realidad".

Disidencia: esta es, efectivamente, la primera palabra que me viene a la mente para calificar la reconstrucción ficcional del pasado en el presente e inversamente, que nos ofrece las Tradiciones, obra magna de Ricardo Palma.

Una obra literaria, que contrariamente a lo sostenido por buena parte de sus contemporáneos, independientemente de las posturas ideológicas y políticas de unos y otros, no glorifica el pasado sino que lo "deconstruye", para decirlo precisamente con palabras del filósofo y ensayista francés Jacques Derrida. Lo deconstruye y lo reconstruye en el presente mediante una 
escritura deicida para mejor cuestionarlo con miras a construir un futuro nuevo y diferente.

Un futuro que se va dibujando en filigrana en el discurso subyacente de Palma, sostenido en un manejo novedoso y original de la técnica escritural.

El escritor juega fundamentalmente sobre tres registros: la reversibilidad de los tiempos, natural y narrativo; la ambigüedad y confusión de los planos, real y ficticio; el humor y el distanciamiento en la expresión de los puntos de vista narrativos.

El tratamiento del tiempo, es probablemente, uno de los puntos claves de las Tradiciones.

Pero desde ahora conviene subrayar que el fenómeno de descontextualización de los hechos y el uso del anacronismo como herramientas narrativas en que se apoya el escritor, no tiene nada que ver con una superposición de períodos históricos distintos.

Se trata de un fenómeno que participa de una construcción original que no destruye las fronteras temporales naturales, aquellas que enmarcan los procesos históricos reales, sino que las niega en el sentido marxiano del término, en un proceso de superación permanente.

De aquí que el tratamiento del tiempo tenga también un significado ideológico que remite al campo de lo político y de lo social.

Sin aventurarme demasiado en la interpretación de las Tradiciones, diré que es una obra de creación que viene a representar, al fin y al cabo, una tentativa de conciliar los valores éticos de una aristocracia que ha desaparecido: la inca, y de otra que 
está desapareciendo: la española y colonial, frente a los valores políticos y sociales a-morales de la nueva sociedad burguesa, liberal y republicana que los está negando.

La disidencia en Palma, se disimula debajo de la máscara de un aparente conformismo social y cultural destinado a cuestionar soterradamente las estructuras del poder colonial y patriarcal y su supervivencia en el Perú republicano.

Y sobre todo, un aparente conformismo social y cultural motivado por el deseo profundo del escritor comprometido con el progreso y el porvenir político de su país, de reflexionar sobre las posibilidades de construir un estado nación, a imagen y semejanza del modelo francés que el afrancesado Ricardo Palma, buen conocedor y adepto declarado de la filosofía de las luces, admira, en un país multiétnico y multicultural como el país en que le ha tocado nacer y vivir.

Las Tradiciones son, efectivamente, una obra multifacética que aborda las grandes problemáticas del momento cuestionándolas desde el punto de vista político, social y cultural a partir de una transgresión estética y formal.

De tal modo que la disidencia escritural en el campo estético y formal se convierte pura y simplemente en expresión de disidencia ideológica, política, social y cultural en el campo de la praxis.

Desde el punto de vista político, social y cultural, miembro de la élite criolla, aunque afrodescendiente de origen modesto, como han señalado sus biógrafos y estudiosos ${ }^{1}$, Palma se encuentra

1 Véanse en especial los trabajos de Oswaldo Holguín: Tiempos de infancia y bohemia. Ricardo Palma (1833-1860), 1994, Lima: Ed. Pontificia Universidad Católica del Perú; y "Ricardo Palma y la cultura negra", en Aguirre, Carlos. Lo africano en la cultura criolla, 2000, pp. 97-120, Lima: Fondo Editorial del Congreso del Perú. 
entre la espada y la pared con la voluntad consciente, que siente como una imperiosa necesidad social de ocultar sus orígenes pardos frente a sus conciudadanos blancos que fingen ignorarlos, y el llamado inconsciente de su yo profundo y de su inconsciente colectivo, como necesidad vital, de no renegar de ellos.

En este difícil juego de escondite entre lo consciente y lo inconsciente, Palma, apoyándose en un estilo preferentemente alusivo y distanciado, opta por una actitud de autocensura personal, pero implícitamente crítica con respecto al ideario criollo de la época, manejando, en el caso de los negros precisamente, más a menudo el concepto de "cultura" que el trillado concepto de "raza" abiertamente discriminatorio y desvalorizante que sigue usando, sin embargo, en algunos casos que sería demasiado largo analizar en el marco del tiempo otorgado en esta mesa redonda.

Un concepto en boga en su época y hasta muy entrado el siglo XX a tal punto que un intelectual comprometido con los valores humanos y éticos de la izquierda revolucionaria más radical como José Carlos Mariátegui, "marxista convicto y confeso", según se presenta él mismo en sus escritos, no dejará de usar en sus ensayos. ${ }^{2}$

En este particular, es sintomático el uso frecuente en las Tradiciones de la autoironía, y también de la falsa modestia en la extremidad opuesta de la autoevaluación.

La humildad fingida en los textos de Palma traiciona la presencia de una alta autoestima que a veces estalla en plena luz como ocurre especialmente en sus cartas a Piérola (en Palma, 2005, p. 165).

2 Remito al respecto a mi libro Mariategui, la utopía realizable. Ed. Minerva, Lima 1995. 
Esto me lleva a pensar que es probablemente este sentimiento profundo de alta autoestima frustrada la que lo lleva al desencanto político y le impide entender las críticas formuladas por los jóvenes intelectuales, capitaneados por Manuel González Prada, de las que se queja en varias cartas a sus amigos. De igual manera que fue, según confiesa él mismo, la frustración política la que lo llevó a la literatura.

Social y políticamente, Palma cuestiona las derivas de la sociedad criolla, su falta de ética, su caudillismo y tendencias autoritarias, el arribismo y egocentrismo de sus miembros a partir de la técnica expositiva e interpretativa del fait divers, o sea de aquello que Unamuno llama la intrahistoria. ${ }^{3}$

Si bien es cierto que el pensamiento de Palma se inscribe en el marco criollo de los valores del cristianismo que es "fraternidad", según afirma, su disidencia se manifiesta en el cuestionamiento de la no adecuación entre la doctrina y su práctica y en los aspectos discriminatorios de su contenido como en la visión y estatuto de la mujer, que en varias tradiciones lleva de algún modo la voz cantante como expresión de su fuerza moral, de su autonomía y libertad, de su capacidad de adaptación, de su voluntad de protesta y del vuelo de su imaginación creadora.

En el ámbito de lo social, si el autor de las Tradiciones aborda discreta y disimuladamente la problemática india y negra, es probablemente más por razones conscientes de eficacia desmitificadora en un contexto de discriminación y de racismo generalizados, que por razones de inconscientes temores cuyas manifestaciones, sin embargo, no se pueden ni se deben descartar.

3 Al respecto, véase mi artículo "Palma y Unamuno: tradición e intrahistoria”, en Aula Palma XV, 2016, pp. 291-304. Lima: Instituto Ricardo Palma. 
Es probablemente también, a pesar de las apariencias, por un llamado, consciente o inconsciente, de rehabilitación de las culturas ancestrales americanas y africanas. Pues como bien afirmaba el gran poeta Leopold Sedar Senghor, "La cebra no puede deshacerse de sus rayas sin dejar de ser Cebra, del mismo modo que el negro no puede deshacerse de su Negritud sin dejar de ser Negro".

El negro, generalmente esclavo, confrontado con el castigo injusto, siempre se encamina al sacrificio "caballero en su burro", o sea, con la dignidad de los nobles y honrados "caballeros" de la Comedia del Siglo de Oro rescatados del pasado, deconstruidos y reconstruidos en el presente por el tradicionista.

En el campo cultural, si Ricardo Palma no niega sus orígenes pardos, no focaliza su reflexión sobre la cultura afroperuana que no ha recibido como legado educativo directo.

En cambio, reconoce, asume y reivindica abiertamente su filiación cristiana europea como elemento central de la cultura criolla en el marco del humanismo de la doctrina religiosa primigenia, confortada éticamente en su adhesión a la masonería.

Una adhesión bastante temprana que sellará definitivamente el carácter fuertemente ético de su escritura y la forma un tanto rígida de su compromiso político y social.

No me parece inútil recordar aquí que, a pesar de su declarado anticatolicismo, de su crítica severa del dogma religioso, Palma lamenta en varios escritos la distensión en la época moderna y republicana de los valores éticos y judeocristianos que Europa impuso en América durante la colonia, hasta el punto de desear la reintroducción de la figura del diablo en la vida diaria para frenar la deriva de la moral cristiana que le sirve de referente. 
Lo que cuestiona Palma no es tanto la desaparición de la doctrina ni del dogma religiosos cuanto la ausencia de moral que gangrena al nuevo Perú republicano, la distensión de los vínculos familiares y matrimoniales, el libertinaje de las costumbres, la sed de riquezas y de poder, el individualismo y la ausencia de solidaridad, la desaparición de lo prohibido y de los tabúes morales, y por lo tanto la negación de la libertad de transgredirlos que caracteriza fundamentalmente al disidente, como dirá más tarde Mario Vargas Llosa.

Desde el punto de vista estético, Palma construye una obra transgenérica, capaz de dar una visión global y totalizadora de la historia y de la realidad de su tiempo.

De aquí la dificultad que tuvo el escritor para definir las Tradiciones con términos conocidos que remitiesen a formas literarias existentes: historia, biografía, crónica, artículo de costumbres, narración histórica, leyenda, fábula, historieta, romance, cuento, que son los términos que el tradicionista va usando más a menudo para referirse a sus escritos.

En ciertos casos, Palma va incluso hasta cambiar las calificaciones de una edición a otra, valiéndose en algunas ocasiones de la forma de la representación teatral, que le permite alcanzar un estilo propio al fusionar el estilo narrativo y el estilo representativo.

Ello se puede observar en varios de sus textos, con la inclusión entre otros elementos del famoso "parrafillo histórico" que viene a completar el protagonismo de los hechos y de los actores, esforzándose por anclar lo ficticio en lo real, creando la ilusión de la autenticidad.

Uno de los puntos claves de la disidencia de Palma está, sin lugar a dudas, en el campo de la cultura y de la lengua. 
Palma reflexiona fundamentalmente sobre la lengua como soporte cultural de la nueva sociedad -como harán más tarde José María Arguedas y Gregorio Martínez de manera mucho más sistemática- y empieza a interrogarse sobre el orden patriarcal, sobre las relaciones de género entre varón y hembra, como elemento discriminatorio, cuestionando implícitamente la visión cristiana de la mujer "ángel y demonio", más demonio que ángel, en el mismo momento en que la franco-peruana Flora Tristán está llevando su cruzada libertaria profeminista.

En este campo como en los demás, si bien Ricardo Palma no pudo desprenderse totalmente del condicionamiento de su cultura ni de su educación criolla y judeocristiana, elige la transgresión como forma de cuestionamiento haciendo a menudo que los negros "cristianados", como los llama, sean mejores cristianos que los cristianos blancos de pura cepa.

Esta inversión de los papeles, es también una manera de invertir simbólicamente la relación colonial amo-esclavo y de rehabilitar al negro en tanto que ser humano.

Pues no lo olvidemos, para Ricardo Palma el cristianismo es "fraternidad", y la esclavitud, la negación de lo humano y, por lo tanto, la peor de las abominaciones, como enfatiza al inicio de su tradición "El rey del monte".

Sin duda, habría mucho más que decir sobre el rico contenido e imprevisible alcance de la obra del patriarca de las letras peruanas.

Una obra que un siglo después del fallecimiento de su autor no ha perdido nada de su poder de convocatoria y ni de su fuerza polémica original, encarnada en los propósitos ultras e iconoclastas del joven Manuel González Prada: "Los viejos a la tumba. Los jóvenes a la obra". 
Aquí dejo tan solo algunas pistas de discusión para alimentar la reflexión sobre la formación del país que no ha dejado de ser de actualidad desde la época de Palma, renovándose permanentemente en escritores como José Carlos Mariátegui, César Vallejo, José María Arguedas, Mario Vargas Llosa y Gregorio Martínez, entre otros, a los que todos tenemos en la memoria.

\section{Referencias}

Blanchot, M. (1955). El espacio literario. París: Gallimard.

Forgues, R. (1995). Mariátegui, la utopía realizable. Lima: Ed. Minerva.

Holguín, O. (1994). Tiempos de infancia y bohemia. Ricardo Palma (1833-1860). Ed. Pontificia Universidad Católica del Perú, Lima.

Holguín, O. (2000). "Ricardo Palma y la cultura negra". En: Aguirre, Carlos. Lo africano en la cultura criolla, pp. 97-120. Lima: Fondo Editorial del Congreso del Perú.

Palma, R. (2005). Epistolario General (1846-1891). Tomo III, Vol. I. Edición, prólogo, notas e índices Miguel Ángel Rodríguez Rea. Lima: Editorial Universitaria de la Universidad Ricardo Palma.

Vargas Llosa, M. (1971). García Márquez: historia de un deicidio. Barcelona: Barral Editores. 